\title{
Ingestive Behavior and Physiological Parameters of Sindhi Heifers Receiving Saline Water
}

\author{
Patrícia R. Rosa ${ }^{1}$, Gherman Garcia L. Araújo ${ }^{2}$, Silvia Helena N. Turco ${ }^{3}$, Salete A. Moraes², Juliana N. Alves ${ }^{4}$, \\ Glayciane C. Gois ${ }^{5}$, Rafael D. Santos ${ }^{2} \&$ Fleming S. Campos ${ }^{6}$ \\ ${ }^{1}$ Postgraduate Program in Animal Science, Federal University of San Francisco Valley, Petrolina, Pernambuco, \\ Brazil \\ ${ }^{2}$ Brazilian Agricultural Research Corporation, EMBRAPA Semiarid, Petrolina, Pernambuco, Brazil \\ ${ }^{3}$ Postgraduate Program in Agricultural Engineering, Federal University of San Francisco valley, Juazeiro, Bahia, \\ Brazil \\ ${ }^{4}$ Animal Production Department, Federal University of Paraíba, Areia, Paraíba, Brazil \\ ${ }^{5}$ Postgraduate Program in Veterinary Sciences in the Semi-Arid, Federal University of San Francisco Valley, \\ Petrolina, Pernambuco, Brazil \\ ${ }^{6}$ Postgraduate Program in Animal Sciences and Pasture, Federal University Rural of Pernambuco, Garanhuns, \\ Pernambuco, Brazil \\ Correspondence: Glayciane Costa Gois, Postgraduate Program in Veterinary Sciences in the Semi-Arid, Federal \\ University of San Francisco Valley, Petrolina, Pernambuco, Brazil. E-mail: glayciane_gois@yahoo.com.br
}

Received: December 22, 2018

Accepted: January 28, 2019 Online Published: March 15, 2019

doi:10.5539/jas.v11n4p381

URL: https://doi.org/10.5539/jas.v11n4p381

\begin{abstract}
The objective was to evaluate the effects of potential use of brackish water as a source for Sindhi heifers on ingestive behavior and physiological and serum parameters. Twenty-four Sindhi heifers were distributed in a completely randomized design with four treatments and six replications, with levels of total dissolved solids (TDS) of $640,3200,5760$, and $8320 \mathrm{mg} / \mathrm{L}$. Three 24-hour behavioral tests were performed, which were divided into four observation shifts $(00: 00$ to $06: 00 ; 06: 00$ to $12: 00 ; 12: 00$ to $18: 00$ and 18:00 to 00:00) at the beginning, middle, and end of the experiment. The highest values of black globe temperature humidity index and air temperature were observed at 14:00 $\mathrm{h}$, with values of 92.7 and $34.1^{\circ} \mathrm{C}$, respectively. The different levels of TDS did not promote significant differences $(\mathrm{P}>0.05)$ in the variables feed intake, rumination, idling, feeding efficiency as a function of dry matter and neutral detergent fiber intake, rumination efficiency as a function of dry matter and neutral detergent fiber intake, heart rate, rectal and surface temperature, creatinine, and potassium. Among the assessed shifts, feed and water intake showed higher frequencies in the shifts $2(06-12 \mathrm{~h})$ and 3 $(12-18 \mathrm{~h})$ and rumination showed a higher frequency in the shifts $1(00-06 \mathrm{~h})$ and $4(18-00 \mathrm{~h})$. The physiological variables presented higher indices during the warmest hours of the day. A linear behavior was observed for the serum sodium level, presenting a average of $134.4 \mathrm{mmol} / \mathrm{L}$. Water containing up to $8,326 \mathrm{mg} / \mathrm{L}$ TDS can be used in the watering of Sindhi heifers in short periods in the season of highest water shortage without affecting the ingestive behavior and physiological and serum parameters of the animal.
\end{abstract}

Keywords: watering, salinity, semiarid

\section{Introduction}

Arid and semiarid regions in the world are the most affected by problems of water resources. It is a fact that governments are increasingly working on supply programs to solve this problem by establishing infrastructures able to providing water and guaranteeing its supply (Cirilo, 2008). In rural areas, this problem is more visible and significant since water is also required for animal watering, which guarantees the production of products of animal origin (Queiroz, D. J. S. Silva, A. C. Silva, \& Pires, 2014). In addition, ruminants are an important part of the economic and social life of these regions and, especially during the dry season, these animals tend to suffer because they consume forages with a low moisture content, low nutritional value, and have irregular and limited access to drinking water (Udimale, Ichikawa, Manandhar, Ishidaira, \& Kiem, 2014). 
According to National Research Council (NRC, 2007), meeting all water requirements for an animal, providing enough for voluntary consumption, is essential for the success of nutritional management. A number of strategies can be used by producers for animal watering in the Brazilian semiarid region, such as water holes, water traps, small weirs, cisterns, and wells (Araújo, Voltolini, Turco, \& Pereira, 2011). However, wells are often the only sources of water (mostly brackish water), especially during periods of prolonged drought.

Animal tolerance to salinity varies according to species, age, need for water, and physiological conditions. The animals can adapt to the salinity of the water to be ingested, but it is recommended its gradual supply since abrupt changes can cause higher losses to water and feed intake (Santos et al., 2014; Paiva et al., 2017). Even though it has a great importance for animal production, the topic "water" does not receive the deserved attention in the technical-scientific scope. Plumb (1927) discussed this subject and pointed out the precarious exploitation of the subject water in ruminant production systems. Few studies address the water as a variable response or present this natural resource as the main objective of the study (Schlink, Nguyen, \& Viljoen, 2010).

The objective was to evaluate the effects of potential use of brackish water as a source for Sindhi heifers on ingestive behavior and physiological and serum parameters.

\section{Method}

\subsection{Study Site}

The experiment was conducted at the Experimental Field of the Caatinga, Sector of Animal Metabolism, belonging to Embrapa Semi-Arid, located in Petrolina, PE-Brazil, (latitude 9 ${ }^{\circ} 8^{\prime} 8.9^{\prime \prime} \mathrm{S}$, longitude $40^{\circ} 18^{\prime} 33.6^{\prime \prime} \mathrm{W}$, altitude $373 \mathrm{~m}$ ). The climate of the region is classified, according to Köppen, as semi-arid of the type BSwh'. The average annual precipitation is $570 \mathrm{~mm}$ and the average annual maximum and minimum temperatures are 33.46 and $20.87^{\circ} \mathrm{C}$, respectively (EMBRAPA, 2014).

\subsection{Animals, Treatments and Experimental Diet}

Twenty-four Sindhi heifers with an average initial body weight (BW) of $170 \pm 5 \mathrm{~kg}$ and an average of 18 months of age were used in a completely randomized design with four treatments and six replications. Before starting the experiment, the animals were weighed, identified with an ear tag number, treated against ecto- and endoparasites, and placed in individual stalls provided with feeding and drinking troughs.

Treatments corresponded to increasing levels of total dissolved solids (TDS) in the water offered to the animals, being reconstituted with sodium chloride $(\mathrm{NaCl})$ distributed into four electrical conductivity levels $(1.0,5.0,9.0$, and $13.0 \mathrm{dS} / \mathrm{m}$ ), allowing a $5 \%$ difference of the limit of each treatment. For converting the electrical conductivity of water to parts per million (ppm) or milligram per liter of total dissolved solids (mg/L TDS), 1 $\mathrm{dS} / \mathrm{m}$ was multiplied by $640 \mathrm{mg} / \mathrm{L}$, according to Marwick (2007). The treatments were converted into milligram per liters in the following proportions: $640,3200,5760$, and $8320 \mathrm{mg} / \mathrm{L}$ TDS. Once a week, the stalls were washed to avoid $\mathrm{NaCl}$ accumulation in the edges, which could influence the salt concentration of each treatment.

Samples of water from each treatment were collected weekly, placed in plastic bottles, identified, and sent to the Agro-environmental Laboratory of the Embrapa Semi-Arid, where chemical analyses were performed, the electrical conductivity of the supplied water was measured (Table 1).

Table 1. Mean values of the variables analyzed in the waters offered for Sindhi heifers during the experimental period

\begin{tabular}{lllll}
\hline \multirow{2}{*}{ Variable } & \multicolumn{3}{c}{ Total dissolved solids in the water $(\mathrm{mg} / \mathrm{L})$} \\
\cline { 2 - 5 } & 640 & 3.188 & 5.740 & 8.326 \\
\hline Electrical conductivity $(\mathrm{dS} / \mathrm{m})$ & 1.00 & 4.98 & 8.97 & 13.01 \\
Total dissolved solids $(\mathrm{g} / \mathrm{L})$ & 0.64 & 3.18 & 5.74 & 8.32 \\
Sodium $(\mathrm{mg} / \mathrm{L})$ & 207 & 1.035 & 2.070 & 3.220 \\
Chlorides $(\mathrm{mg} / \mathrm{L})$ & 542.38 & 1.898 & 3.073 & 3.977 \\
Calcium $(\mathrm{mg} / \mathrm{L})$ & 13.80 & 15.00 & 15.20 & 17.00 \\
Magnesium $(\mathrm{mg} / \mathrm{L})$ & 17.52 & 13.68 & 9.48 & 10.50 \\
Potassium $(\mathrm{mg} / \mathrm{L})$ & 1.95 & 2.74 & 2.93 & 3.51 \\
Alkalinity $(\mathrm{mg} / \mathrm{L})$ & 13.6 & 14.00 & 14.35 & 14.80 \\
\hline
\end{tabular}


The diet of animals was composed of a 50:50 proportion of buffelgrass hay (Cenchrus ciliaris) and concentrate based on soybean meal, ground corn, and mineral supplement (Table 2). The diet and water were offered twice daily at 08:00 and 16:00 h. The quantity was calculated based on the consumption of the previous day, always considering $10 \%$ leftovers. Weekly samples of the offered feed and leftovers were collected and sent to the laboratory for further bromatological analisys.

Drinking water was weighed before supply and its intake was recorded daily. Three buckets containing water were distributed in the shed to determine the evaporation rate.

Table 2. Chemical composition of ingredients offered in the experimental diet

\begin{tabular}{|c|c|c|c|c|c|}
\hline \multirow{2}{*}{ Fraction $(\%)$} & \multicolumn{4}{|c|}{ Ingredients } & \multirow{2}{*}{ Total Diet (50:50) } \\
\hline & Buffel-grass hay & Soybean meal & Ground corn & Mineral supplement & \\
\hline Dry matter $^{\mathrm{a}}$ & 81.13 & 86.81 & 87.07 & 99.07 & 84.26 \\
\hline Organic matter $(\% \mathrm{DM})$ & 92.95 & 93.39 & 98.27 & 10.71 & 93.15 \\
\hline Mineral matter (\%DM) & 7.05 & 6.61 & 1.73 & 89.29 & 6.84 \\
\hline Crude protein $(\% \mathrm{DM})$ & 3.81 & 51.62 & 9.33 & - & 14.09 \\
\hline $\mathrm{NDFap}^{\mathrm{b}}(\% \mathrm{DM})$ & 77.63 & 18.01 & 20.67 & - & 48.29 \\
\hline $\operatorname{ADFap}^{\mathrm{c}}(\% \mathrm{DM})$ & 63.05 & 20.57 & 9.07 & - & 37.98 \\
\hline $\operatorname{ADIN}^{\mathrm{d}}(\% \mathrm{DM})$ & 0.36 & 0.49 & 0.33 & - & 0.37 \\
\hline $\mathrm{NDIN}^{\mathrm{e}}(\% \mathrm{DM})$ & 0.30 & 0.74 & 0.56 & - & 0.45 \\
\hline Ether extract (\%DM) & 1.60 & 1.60 & 5.63 & - & 2.78 \\
\hline \multicolumn{6}{|l|}{ Total carbohydrates (\%DM) } \\
\hline Non-fibrous carbohydrates (\%DM) & 9.22 & 22.16 & 62.64 & - & 28.00 \\
\hline Lignin $(\% \mathrm{DM})$ & 13.99 & 0.15 & 0.86 & - & 7.28 \\
\hline Hemicellulose (\%DM) & 14.58 & 2.56 & 11.60 & - & 10.31 \\
\hline Cellulose (\%DM) & 29.43 & 20.42 & 8.21 & - & 30.70 \\
\hline Total digestible nutrients (\%DM) & - & - & - & - & 60.33 \\
\hline
\end{tabular}

Note. ${ }^{\mathrm{a} I n} \%$ fresh matter; ${ }^{\mathrm{b}} \mathrm{NDFap}=$ neutral detergent fiber corrected for ash and protein; ${ }^{\mathrm{c}} \mathrm{ADFap}=$ acid detergent fiber corrected for ash and protein; ${ }^{\mathrm{d}} \mathrm{ADIN}$ : acid detergent insoluble nitrogen; ${ }^{\mathrm{e}} \mathrm{NDIN}$ : neutral detergent insoluble nitrogen.

\subsection{Laboratory Analysis}

Laboratory analyses were carried out at the Laboratory of Animal Nutrition of the Embrapa Semi-Arid using the methods described by AOAC (2000) for dry matter (DM; method 967.03), mineral matter (MM; method 942.05), crude protein (CP; method 981.10), and ether extract (EE; method 920.29). Neutral detergent fiber content corrected for ash and protein (NDFap), determined using sodium sulfite-free thermostable alpha-amylase, and acid detergent fiber (ADF) were obtained according to the methodology described by Van Soest, Robertson and Lewis (1991). Lignin was determined by treating the fiber residue in acid detergent with $72 \%$ sulfuric acid (Silva \& Queiroz, 2002). Hemicellulose (HEM) was calculated by means of the equation:

$$
\mathrm{HEM}=\mathrm{NDF}-\mathrm{ADF}
$$

Total carbohydrates (TC) were calculated using the equation proposed by Sniffen, O'Connor, Van Soest, Fox and Russell (1992):

$$
\mathrm{TC}(\% \mathrm{DM})=100-(\mathrm{CP}+\mathrm{EE}+\text { ashes })
$$

Non-fibrous carbohydrate (NFC) contents were calculated as proposed by HALL (2000):

$$
\mathrm{NFCap}=\% \mathrm{TC}-\% \mathrm{NDFap}
$$

\subsection{Ingestive Behavior}

In order to assess the ingestive behavior of animals, three tests were performed: at the beginning, middle, and end of the experiment. The animals were observed for 24 hours divided into four six-hour periods to determine the time spent on ingestion, rumination, and idling, according to the methodology cited by Johnson \& Combs (1991). The data were collected by trained observers using of digital timers and the events were recorded at 10-minute intervals. During the night observations, the environment was maintained under artificial light. 
Feeding and rumination efficiency as a function of DM and neutral detergent fiber were calculated according to equations adapted from Bürger et al. (2000), where,

$$
\begin{aligned}
\text { FEDM } & =\text { DMI/TFE }(\mathrm{g} \mathrm{DM} / \mathrm{h}) \\
\text { REDM } & =\text { DMI/TRU }(\mathrm{g} \mathrm{DM} / \mathrm{h}) \\
\text { FENDF } & =\text { NDFI/TFE }(\mathrm{g} \mathrm{NDF} / \mathrm{h}) \\
\text { RENDF } & =\text { NDFI/TRU }(\mathrm{g} \mathrm{NDF} / \mathrm{h})
\end{aligned}
$$

in which, FEDM is the feeding efficiency as a function of dry matter intake, REDM is the rumination efficiency as a function of dry matter intake, FENDF is the feeding efficiency as a function of neutral detergent fiber intake, RENDF is the rumination efficiency as a function of neutral detergent fiber intake, and DMI is the dry matter intake (g DM/day).

\subsection{Physiological Parameters}

The physiological data were collected after the assessment of ingestive behavior in a period of 12 hours (09:00, 11:00, 13:00, 15:00, 17:00, 19:00, and 21:00 h). Rectal temperature (RT), heart rate (HR), and surface temperature (ST) were obtained at each of these determined times. The rectal temperature was measured by using a veterinary clinical thermometer inserted into the animal's rectum for two minutes. Heart rate was obtained by counting the number of movements during 15 seconds with a flexible stethoscope placed directly over the left thoracic region at the approximate height of the aortic arch. The value was multiplied by four to obtain the heart rate in beats per minute. The surface temperature was obtained with a digital infrared thermometer placed at three determined points of the animal's body (forehead, hump, and thigh) and calculated the mean of these three temperatures.

\subsection{Serum Parameters}

Three blood samples were collected through of venipuncture of the jugular in vacutainer-type tubes without the addition of anticoagulants. After collection, the samples were centrifuged for 15 minutes at $7000 \mathrm{rpm}$ and then, with an automatic pipette, the serum was removed and evenly distributed in properly identified eppendorf tubes, which were kept under refrigeration and transferred to the laboratory for analyses.

The environmental variables recorded were the black globe temperature (BGT) through the Vernon black globe thermometer and the dry- (DBT) and wet-bulb temperature (WBT) using of the dry- and wet-bulb thermometer. The black globe temperature humidity index (BGTHI) was determined according to Buffington et al. (1981):

$$
\mathrm{BGTHI}=\mathrm{BGT}+0.36 \mathrm{DPT}+41.5
$$

In which BGT is the black globe temperature $\left({ }^{\circ} \mathrm{C}\right)$, and DPT is the dew-point temperature $\left({ }^{\circ} \mathrm{C}\right)$. Readings were performed on the same days of the behavioral tests during 24 hours at 1-hour intervals and at all experimental environments, according to international meteorological standards.

\subsection{Statistical Analysis}

Data were analyzed using the Statistic Analysis System 9.0 (SAS Institute, Cary, NC, USA) (SAS, 2009). Analysis of variance was performed using the PROC GLM. Differences were significant when the P-value was less than $5 \%$.

\section{Results}

The environmental variables air temperature, black globe temperature humidity index, relative humidity (RH), and others are shown in Figure 1. The highest values of BGTHI was 92.7 at 14:00 $\mathrm{h}$. The minimum value of BGTHI was 71.6 at 04:00 and 16:00 h, respectively. RH presented an average of $76.8 \%$.

Dry matter intake, daily weight gain and feed conversion did not differ between treatments (Table 3), presenting average values of $4.12 \mathrm{~kg} / \mathrm{day}, 0.56 \mathrm{~kg} / \mathrm{day}$, and 8.21 , respectively. An increasing linear effect was observed for water consumption at the drinking trough $(\mathrm{P}=0.009)$ as TDS levels increased, presenting a higher water consumption at the drinking trough at a level of $8,326 \mathrm{mg} / \mathrm{L}$ TDS $(24.93 \mathrm{~L} /$ day $)$.

Regarding the ingestive behavior, salinity levels did not affect the percentages of time of feed intake, rumination, and idling (Figures 2, 3, and 4). However, differences were observed between shifts for these parameters. A difference $(\mathrm{P}<0.05)$ was observed for the time of FI, with the highest percentages for shifts $2(06: 00-12: 00 \mathrm{~h})$ and 3 (12:00-18:00 h), i.e. the diurnal period (Figure 2). 


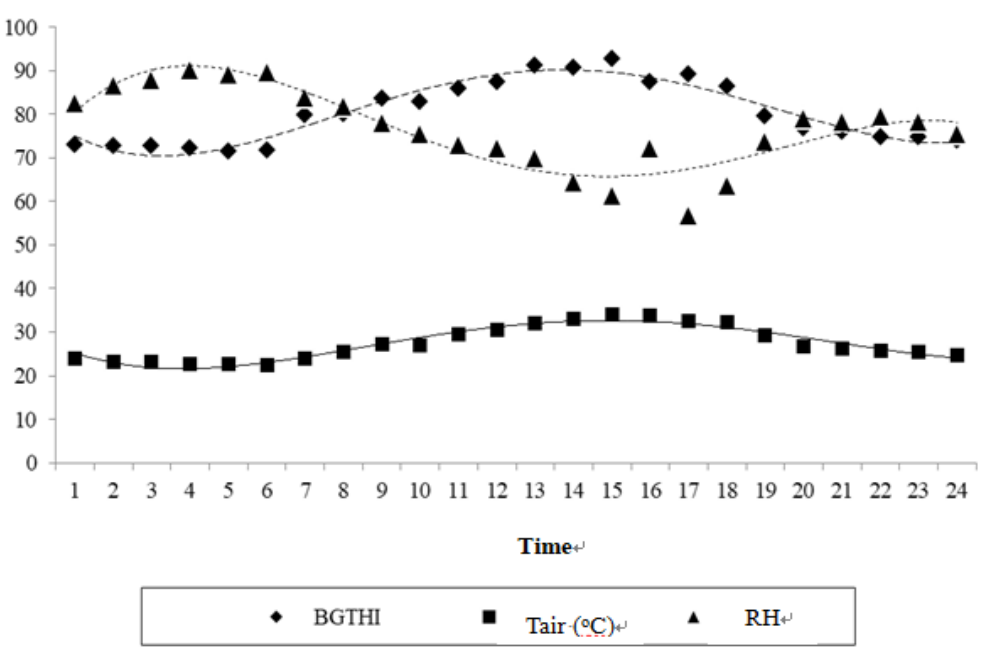

Figure 1. Black Globe Temperature and Humidity Index (BGTHI), Air Temperature (Tair) and Relative Humidity $(\mathrm{RH})$ of the air in the experimental period

Table 3. Dry matter intake (DMI), water consumption at the drinking trough (WDT), daily weight gain (DWG) and feed conversion (FC) of Sindhi heifers receiving water with different concentrations of Total Dissolved Solids

\begin{tabular}{lllllllll}
\hline \multirow{2}{*}{ Variables } & \multicolumn{4}{c}{ Total dissolved solids $(\mathrm{mg} / \mathrm{L})$} & \multirow{2}{*}{ Mean } & \multirow{2}{*}{ SEM $^{\mathrm{a}}$} & \multicolumn{3}{c}{ P-value } \\
\cline { 2 - 5 } & 640 & 3.188 & 5.740 & 8.326 & & & Linear & Quadratic \\
\hline DMI (kg/day) & 4.3 & 4.05 & 4.12 & 4.04 & 4.12 & 0.13 & 0.552 & 0.748 \\
WDT (L/day) & 15.55 & 21.13 & 23.59 & 24.93 & 21.3 & 1.34 & 0.009 & 0.152 \\
DWG (kg/day) & 0.58 & 0.53 & 0.61 & 0.51 & 0.56 & 0.02 & 0.471 & 0.611 \\
FC (kg/day) & 7.78 & 8.3 & 8.44 & 8.32 & 8.21 & 0.28 & 0.495 & 0.597 \\
\hline
\end{tabular}

Note. ${ }^{\text {a }} \mathrm{SEM}=$ Standard error of the mean.

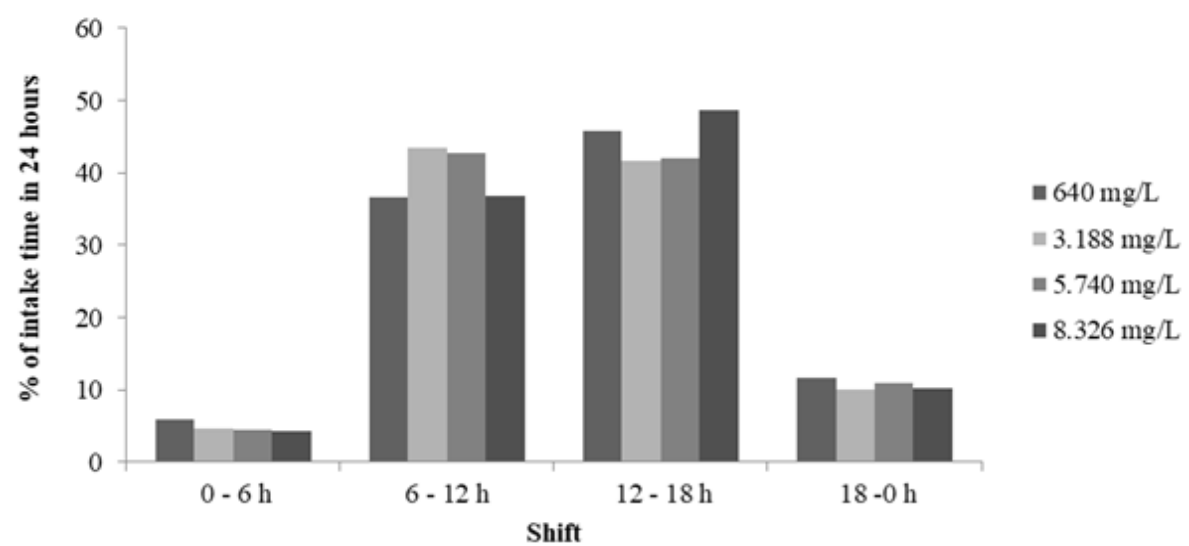

Figure 2. Distribution of the Intake percentage in 24 hours, subdivided into four shifts according to the different levels of Total Dissolved Solids (TDS)

No differences $(\mathrm{P}>0.05)$ were observed between salinity levels of drinking water over the time of RU within each shift. However, a difference $(\mathrm{P}<0.05)$ was observed in the percentage of time of RU (Figure 3 ), in which the animals spent more time ruminating in shifts $1(00: 00-06: 00 \mathrm{~h})$ and $4(18: 00-00: 00 \mathrm{~h})$.

The different salinity levels did not affect $(\mathrm{P}>0.05)$ the idling time within the assessed shifts. However, a difference $(\mathrm{P}<0.05)$ was observed for idling time in the different shifts, presenting a higher percentage of idling time in shift 1 (00:00-06:00 h) (Figure 4). 
Regarding the percentage of water intake, no differences $(\mathrm{P}>0.05)$ were observed for the different water salinity levels within the assessed shifts. However, a difference $(\mathrm{P}<0.05)$ was observed for this parameter between shifts, with higher values for shifts 2 (06:00-12:00 h) and 3 (12:00-18: 00h) (Figure 5).

Frequencies of water intake and urination presented a quadratic behavior $(\mathrm{P}<0.05)$, with higher values for the treatment containing $8,326 \mathrm{mg} / \mathrm{L}$ TDS. The frequency of defecation showed an increasing linear effect $(\mathrm{P}<0.05)$ as TDS levels in drinking water increased (Table 4).

No differences $(\mathrm{P}>0.05)$ were observed in the variables FEDM, FENDF, REDM, and RENDF, with averages of $1107.62,599.2,739.62$, and $400.1 \mathrm{~g} / \mathrm{h}$, respectively (Table 5).

Regarding the physiological parameters heart rate (HR) and rectal (RT) and superficial temperatures (ST), no significant $(\mathrm{P}>0.05)$ was observed between the different studied salinity levels. However, a difference $(\mathrm{P}<0.05)$ was observed between the assessment times $(09: 00,11: 00,13: 00,15: 00,17: 00,19: 00$, and 21:00 h). A difference was observed between times for the heart rate $(\mathrm{P}<0.05)$, with higher values at 15:00 $\mathrm{h}$ (Figure 6), when the animals presented an average of 100 beats/min. This fact may have occurred due to the high temperature observed at this time (Figure 1).

Rectal temperature (RT) varied from 37.9 to $38.5^{\circ} \mathrm{C}$, with a difference between the assessed times $(\mathrm{P}<0.05)$, when the animals had the highest RT values during the warmest times of the day (13:00, 15:00, and 17:00 h, respectively) (Figure 7).

The average ST was $36.5{ }^{\circ} \mathrm{C}$, ranging from 35.8 to $37.6{ }^{\circ} \mathrm{C}$. In addition, ST was not affected by different water salinity levels, but there was an increase in times with the highest radiation index (11 to $15 \mathrm{~h}$ ) and then a decrease of this variable (Figure 8).

Serum creatinine and potassium concentrations did not differ $(\mathrm{P}>0.05)$ between the different TDS levels, showing average values of $0.99 \mathrm{mg} / \mathrm{dL}$ and $4.2 \mathrm{mmol} / \mathrm{L}$, respectively (Table 6). A linear increase $(\mathrm{P}<0.05)$ was observed between salinity levels for serum sodium levels, with an average of $134.4 \mathrm{mmol} / \mathrm{L}$.

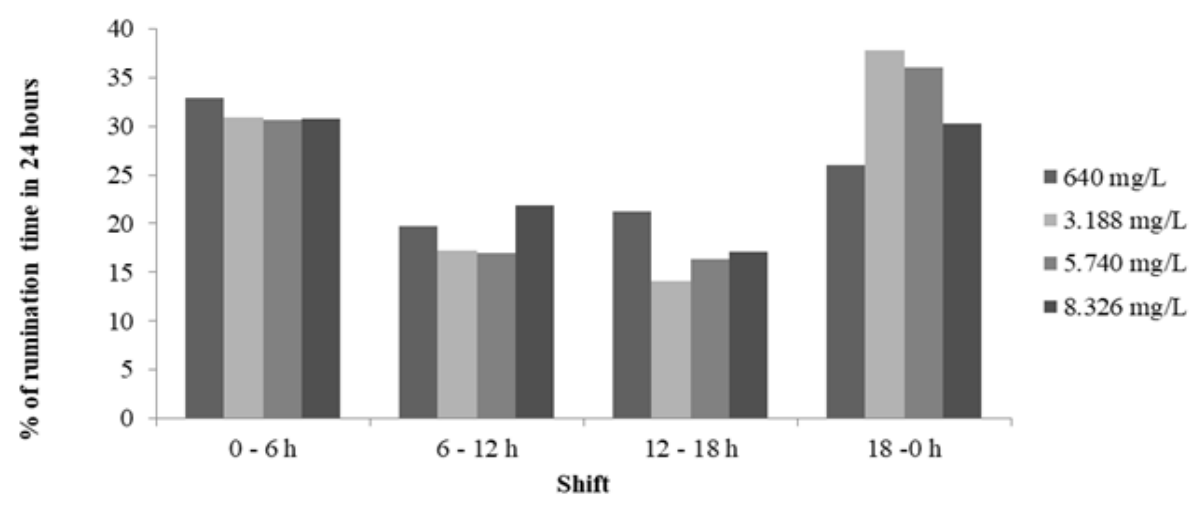

Figure 3. Distribution of the rumination percentage in 24 hours, subdivided into four shifts according to the different levels of Total Dissolved Solids (TDS) 


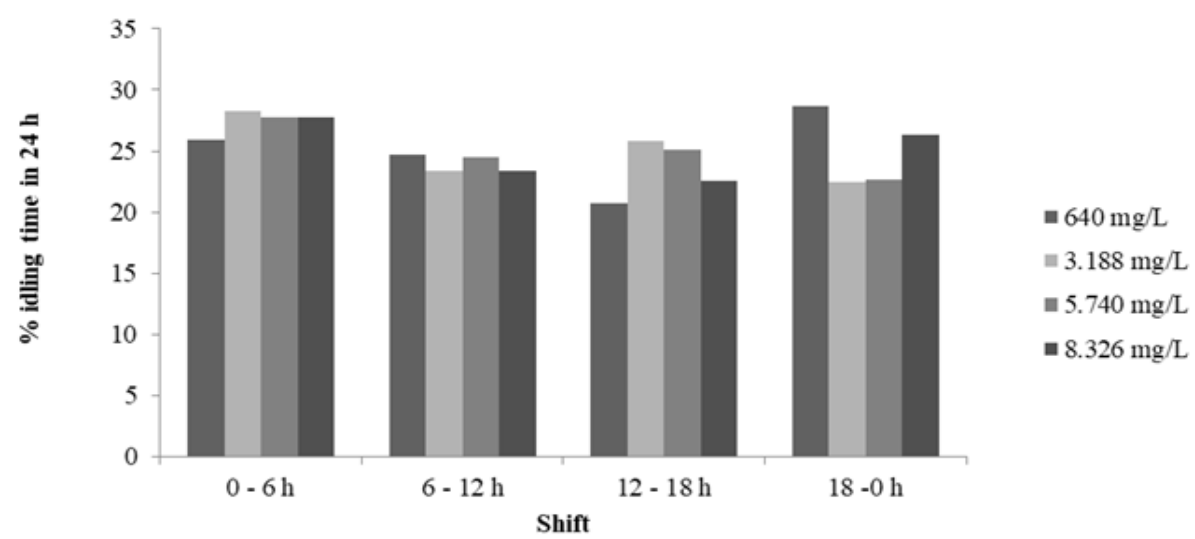

Figure 4. Distribution of the idling time percentage in 24 hours, subdivided in four shifts according to the different levels of Total Dissolved Solids (TDS)

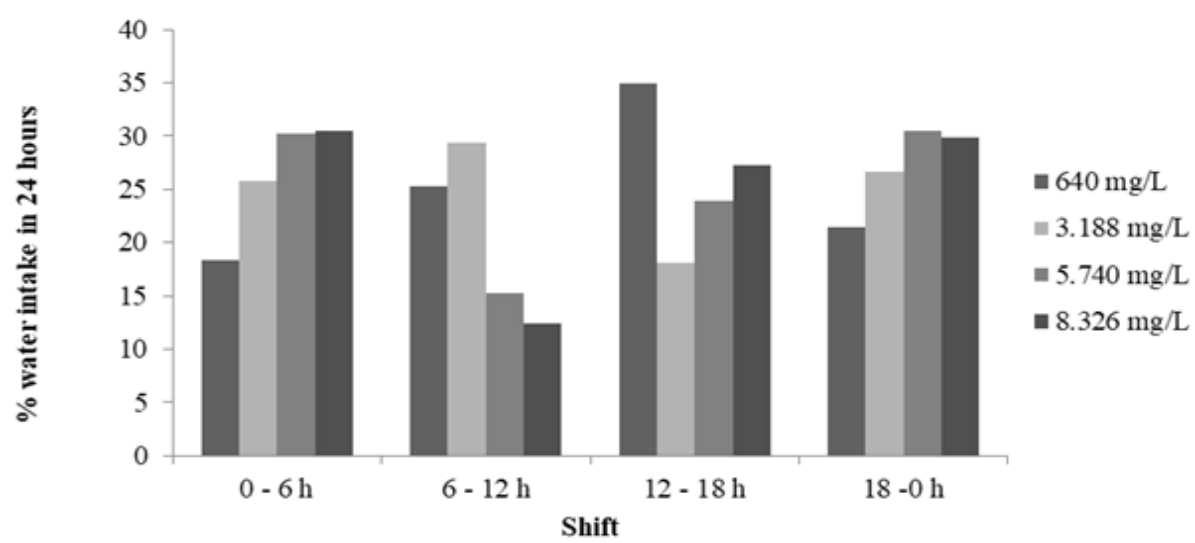

Figure 5. Distribution of water intake percentage in 24 hours, subdivided into four shifts according to the different levels of Total Dissolved Solids (TDS)

Table 4. Frequencies of water intake (WI), urination (U) and defecation (D) of Sindhi heifers receiving water with different levels of Total Dissolved Solids

\begin{tabular}{|c|c|c|c|c|c|c|c|c|}
\hline \multirow{2}{*}{ Frequencies (times/day) } & \multicolumn{4}{|c|}{ Total Dissolved Solids (mg/L) } & \multirow{2}{*}{ Mean } & \multirow{2}{*}{$\mathrm{SEM}^{\mathrm{a}}$} & \multirow{2}{*}{ Equation } & \multirow{2}{*}{$\mathrm{R}^{2}$} \\
\hline & 640 & 3.188 & 5.740 & 8.326 & & & & \\
\hline Water intake & 10.9 & 10 & 15.9 & 15 & 12.95 & 0.94 & $\hat{y}=9.78+0.0007 x-2.81 x^{2}$ & 0.59 \\
\hline Urination & 9.7 & 13.2 & 18.5 & 16.2 & 14.4 & 1.87 & $\hat{y}=7.5+0.002 x-2.20 x^{2}$ & 0.38 \\
\hline Defecation & 6.1 & 7.2 & 8.8 & 9 & 7.7 & 0.47 & $\hat{y}=6.02+0.0004 x$ & 0.56 \\
\hline
\end{tabular}

Note. ${ }^{\text {a }} \mathrm{SEM}=$ Standard error of the mean

Table 5. Means of feed efficiency and rumination efficiency of Sindhi heifers receiving water with different levels of Total Dissolved Solids

\begin{tabular}{lllllllll}
\hline \multirow{2}{*}{ Variables $(\mathrm{g} / \mathrm{h})$} & \multicolumn{3}{c}{ Total dissolved solids $(\mathrm{mg} / \mathrm{L})$} & \multirow{2}{*}{ Mean } & \multirow{2}{*}{$\mathrm{SEM}^{\mathrm{a}}$} & & \multicolumn{2}{c}{ P-value } \\
\cline { 2 - 5 } & 640 & 3.188 & 5.740 & 8.326 & & & \\
\hline FEDM & 1192.9 & 1045.9 & 1107.8 & 1083.9 & 1108 & 55.74 & 0.307 & 0.337 \\
FENDF & 645.3 & 565.8 & 599.3 & 586.4 & 599.2 & 24.67 & 0.793 & 0.128 \\
\hdashline REDM & 703.4 & 782.0 & 791.3 & 681.8 & 739.6 & 45.61 & 0.793 & 0.128 \\
RENDF & 380.5 & 423.0 & 428.1 & 368.8 & 400.1 & 24.67 & 0.793 & 0.128 \\
\hline
\end{tabular}

Note ${ }^{\text {a }} \mathrm{SEM}=$ Standard error of the mean. FEDM $=$ feeding efficiency as a function of dry matter intake; FENDF $=$ feeding efficiency as a function of neutral detergent fiber intake; REDM = rumination efficiency as a function of dry matter intake; RENDF rumination efficiency as a function of neutral detergent fiber intake. 


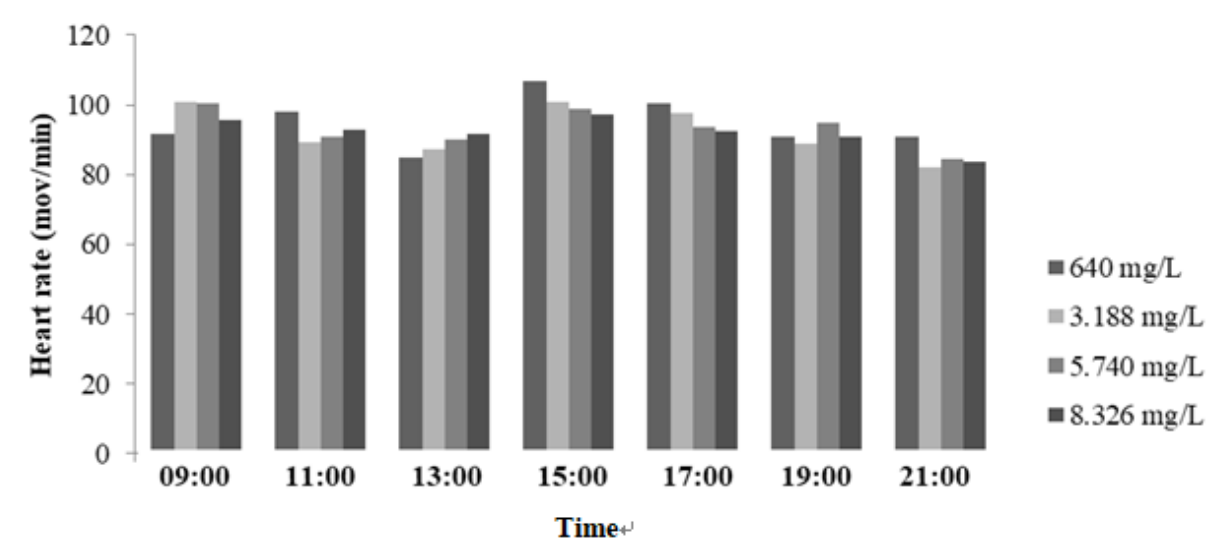

Figure 6. Mean heart rate (HR) values of Sindhi heifers receiving water with different levels of Total Dissolved Solids (TDS) at different times

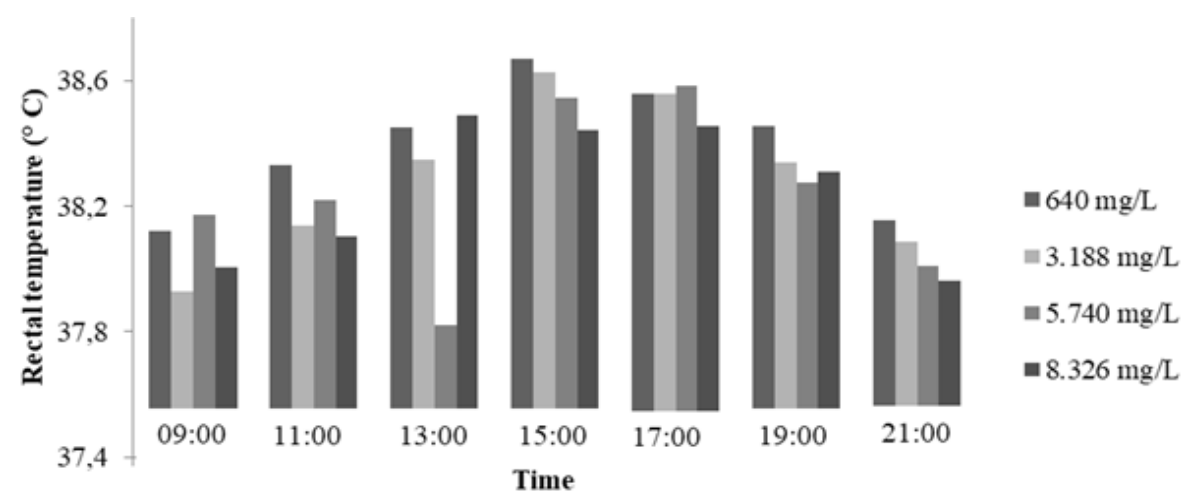

Figure 7. Mean values of rectal temperature (RT) of Sindhi heifers receiving water with different levels of Total Dissolved Solids (TDS) at different times

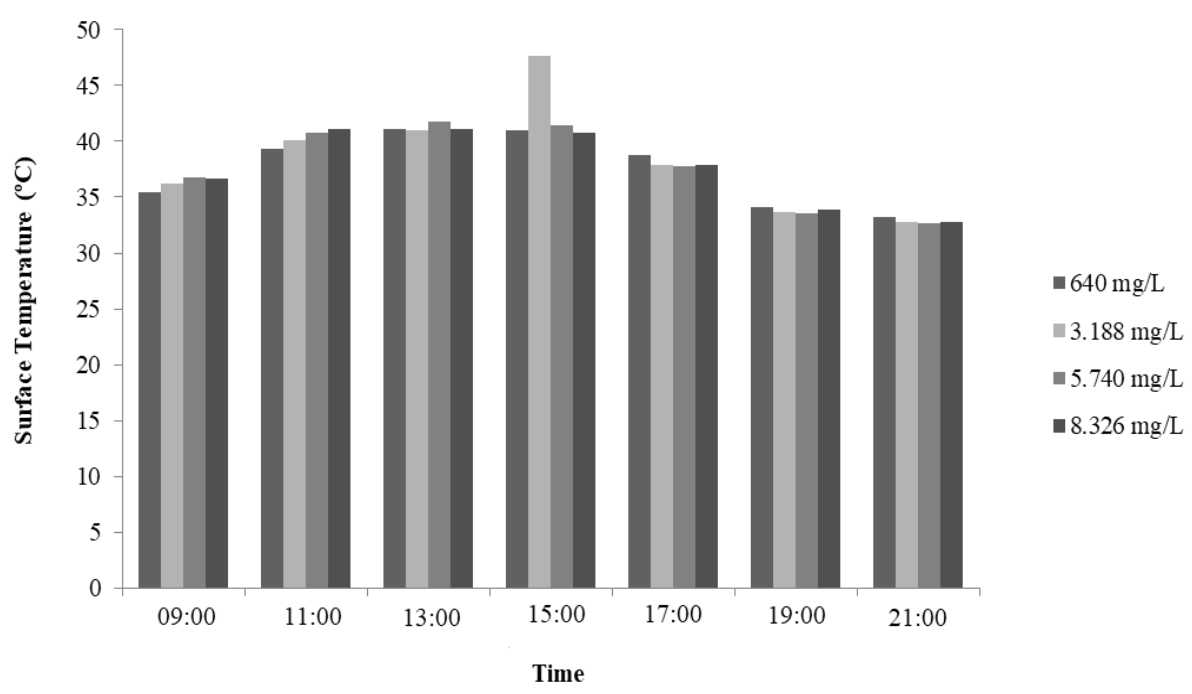

Figure 8. Mean values of surface temperature (TS) of Sindhi heifers receiving water with different levels of Total Dissolved Solids (TDS) at different times 
Table 6. Means of serum creatinine, sodium and potassium parameters in Sindhi heifers receiving water with different levels of Total Dissolved Solids

\begin{tabular}{|c|c|c|c|c|c|c|c|c|}
\hline \multirow{2}{*}{ Variables } & \multicolumn{4}{|c|}{ Total Dissolved Solids (mg/L) } & \multirow{2}{*}{ - Mean } & \multirow{2}{*}{ SEM $^{\mathrm{a}}$} & \multirow{2}{*}{ Equation } & \multirow{2}{*}{$\mathrm{R}^{2}$} \\
\hline & 640 & 3188 & 5740 & 8326 & & & & \\
\hline Creatinine (mg/dL) & 1.0 & 1.0 & 1.0 & 0.96 & 0.99 & 0.04 & ns & - \\
\hline Sodium (mmol/L) & 132 & 135.2 & 134.8 & 135.7 & 134.4 & 0.84 & $\hat{y}=132.56+0.0004 x$ & 0,37 \\
\hline Potassium $(\mathrm{mmol} / \mathrm{L})$ & 4.1 & 4.4 & 4.3 & 4.3 & 4.2 & 0.11 & ns & - \\
\hline
\end{tabular}

Note. ${ }^{\mathrm{a}} \mathrm{SEM}=$ Standard error of the mean; $\mathrm{ns}=$ not significant.

\section{Discussion}

The Livestock Weather Safety Index quantified environmental conditions using the THI and it described the heat stress zone into four categories with different range of THI under each category like normal $(\leq 74)$, alert $(74<$ THI $<79)$, danger stress $(79 \leq \mathrm{THI}<84)$ and emergency stress (THI $\geq 84)$ in livestock (Dash et al., 2016). But these values are used for the temperate North American climate. The conditions of the semiarid are different. According to the results, the animals showed to be well adapted to emergency levels. The average values are close to those found by Oliveira et al. (2012), who assessed Sindhi steers in the semiarid region of Pernambuco and observed BGTHI values of 71.7 and 87.2 at 05:00 h.

The RH value is above that considered as adequate for most production animals, which should range 60 and $70 \%$ according to Das et al. (2016). Although the RH value was considered above the normal, the stress condition only occurred when associated with a high air temperature, which presented an average of $27.4{ }^{\circ} \mathrm{C}$, with a maximum of $34.1^{\circ} \mathrm{C}$ at $14: 00 \mathrm{~h}$ and a minimum of $22.4^{\circ} \mathrm{C}$ at 05:00 h. According to Furtado et al. (2012), an air temperature ranging between from 16 to $28{ }^{\circ} \mathrm{C}$ is considered as a thermal comfort zone for Bos indicus. Therefore, the animals used in this study were not under a thermal comfort zone, reaching this condition only at nighttime.

The values obtained for dry matter intake (kg/day) are close to that recommended of $4.4 \mathrm{~kg} / \mathrm{day}$ for animals with $250 \mathrm{~kg}$ and DWG of $0.500 \mathrm{~kg}(\mathrm{NRC}, 1996)$. Thus, that different salinity levels in drinking water were not able to affect DMI possibly because it did not cause effects on the ruminal microbiota due to factors such as the high tolerance of ruminal microorganisms to salinity (Potter, Walker, \& Forrest, 1971; Johansson, 2008).

Water intake offered in the drinking trough was above that considered normal for cattle of $100 \mathrm{~kg} / \mathrm{BW}$ and at temperatures higher than $27^{\circ} \mathrm{C}$, which is from 16 to $18.6 \mathrm{~L}$ /day (Church, 1993). A similar behavior was observed by Valtorta et al. (2007), who verified that higher TDS levels in the drinking water of lactating Dutch cows promoted a higher water intake. This increase in water intake can be explained by the high level of salt contained in this water, which increased the need to ingest water (Rakova et al., 2017). However, this consumption for domestic animals should be provided in a gradual manner, favoring the adaptation and acceptability of a lower quality water, avoiding their interference in the intake and digestibility of nutrients (Araújo, Voltolini, Chizzotti, Turco, \& Carvalho, 2010).

The National Research Council (2001) recommends that cattle should ingest water with a maximum of 7000 $\mathrm{mg} / \mathrm{L}$ TDS and higher values may cause metabolic disorders and, consequently, performance problems. However, no metabolic disturbance was observed in the animals of the present study. This implies that animals can intake water with up to $8326 \mathrm{mg} / \mathrm{L}$ without causing damage to their performance.

Appuhamy, Judy, Kebreab and Kononoff (2016) stated that water intake is associated with a high salinity content and high ambient temperature. The animals of the present study were under shaded screens with $70 \%$ shading and, under these conditions, they could be under a heat stress condition since the material used did not guarantee a total protection against the incidence of solar radiation. Therefore, according to Schütz, Lee and DeVries (2018), these conditions favor mineral loss through saliva, sweat, and urine, and the animal tends to drink more water to maintain the hydroelectrolytic balance.

According to Segabinazz et al. (2014), animals in confinement have the availability of feed at fixed periods, so the intake activity becomes diurnal. This behavior is due to the psychogenic fact since the frequency of supplying favors the stimulus of voluntary intake.

The FI time observed in this study corroborates the results of Pinto et al. (2010), who stated that activities performed by animals during the day are not homogeneous, with a longer time of feed intake from 6:15 to 18:00 $\mathrm{h}$ for confined crossbred bulls fed three different diets and water ad libitum. These differences were attributed to 
the fact that the animals were housed and receiving diets at 9:00 and 15:00 h, that is at the same time as the present study. Within this period, the authors also observed that the highest frequency of feed intake was observed between 12:15 and 18:00 $\mathrm{h}$ due to a higher feed availability.

The animals of this study spent more time ruminating in the cooler hours of the day. According to Oliveira et al. (2012), increases in the time of rumination occur in cooler periods of the day, being this activity responsible for a higher release of heat increment and the option to ruminate at times with milder temperature may reflect the adaptive capacity of these animals to warm climate regions.

There is an inverse relationship between feeding and rumination time (Pahl, Hartung, Mahlkow-Nerge, \& Haeussermann, 2016). This fact was proven in this study since there was a higher FI time in the diurnal period, with a lower RU time at this period and an opposite behavior at night. This result corroborates Oliveira et al. (2012), who also observed higher rumination times at night. Therefore, the different salinity levels provided to the animals were not enough to alter rumination behavior since the results observed in the present study are considered normal.

Rumination and idling periods occur between meals and have duration and distribution pattern influenced by ingestion activities (Pazdiora et al., 2011; Geron et al., 2018). In this sense, the animals intercalated activities of rumination and idling in shift 1, corresponding to the period between 00:00-06:00 $\mathrm{h}$.

The habit of water intake follows feed intake and the intake peak coincides with dry matter intake even when the feed is offered several times a day (Almeida et al., 2013). In this study, the highest percentages of time of feed and water intake occurred during the same period. Shift $3(12: 00-18: 00 \mathrm{~h})$ was the period with higher values of air temperature and BGTHI. Therefore, animals need to ingest more water to ensure the control of their body temperature.

The more salts the animal consumes, the more water they will also consume because without the balance between water and mineral salts, especially sodium and potassium, kidney reabsorption reactions are not possible, generating a hydroelectrolytic imbalance. Salts need to be present in the medium so that there is water reabsorption by the kidneys. These results are in accordance with water intake, which increased according to the higher TDS in the water.

Urine and feces are means of eliminating water and salts from the body. Therefore, when animals drink more water and ingest more salt, the frequency of urination and defecation is higher because kidneys balance these levels of water and salts in the body and tend to excrete more when under higher concentrations of these substances (Guyton \& Hall, 2011). Valente-Campos, Nascimento and Umbuzeiro (2014) and Beyene (2016) observed that the frequency of elimination of substances from the organism is related to environmental variations, water intake, and volume, quality, and type of feed consumed by the animals.

The similarity in rumination and feeding times may have contributed to the lack of difference between treatments. For Oliveira, Castro, Herculano, Mourthé and Santos (2016), feeding and rumination efficiencies are primarily affected by animal intake, which can promote changes in feeding, rumination, and idling times. Oliveira et al. (2012) evaluated Sindhi steers fed different old man saltbush (Atriplex nummularia Lindl.) hay levels and fresh water ad libitum and did not report differences for FEDM, FENDF, REDM, and RENDF. Therefore, salt contents in animal feed in both diet and water possibly do not influence these in the evaluated levels parameters.

According to Correia et al. (2012), HR of cattle is considered normal between 48 and 80 beats $/ \mathrm{min}$. The animals of this study presented an HR above the normal range. This may be associated with the environmental temperature together with the animal heat production, which can alter the vagal tone, intensifying the activities of the cardioaccelerator and vasoconstrictor centers, thus increasing heart rate. This effect occurs, presumably, because excessive heat increases the ionic permeability of the cell membrane, resulting in an acceleration of the process of self-excitation (Guyton \& Hall, 2011).

Higher rectal temperature (RT) indices at the warmest times of the day were probably due to an increase in the additional thermal load received by solar radiation, increasing the amount of internal heat (Souza et al., 2007). Although BGTHI values were high at these times, RT remained within the variation of the rectal temperature of 36 to $39.1{ }^{\circ} \mathrm{C}$ for cattle (Chacur et al., 2016). Rectal temperature is an indicator of thermal balance and can be used to assess the adversity of thermal environment, as the increase in rectal temperature may indicate that the mechanisms of heat release have become insufficient (Rejeb, Sadraoui, Najar, \& M'rad, 2016).

According to Nascimento, Cardoso, Batista, Souza and Cambuí (2013), rectal temperature varies in animals active during the day, which is minimal in the morning and maximum in the afternoon. However, under thermal stress, mainly in the afternoon, the variation of rectal temperature evidence hyperthermia in this period. This fact 
makes the air temperature in the afternoon to be the origin of a high rectal temperature in the tropics, especially in the summer. Therefore, it can be used to assess the thermal stress level of animals during this period as rectal temperature measurement is often used as an index of physiological adaptability to warm environments because its increase shows that mechanisms of heat release became inefficient (Randhawa, Chhabra, Randhawa, Zahid, \& Dhaliwa, 2014). The fact that animals showed a normal RT despite the high BGTHI value shows their efficient mechanisms to maintain homeothermia and that water salinity levels do not affect this balance.

An increase in surface temperature reflects an increase in ambient temperature, thus not characterizing the body temperature of animals (Shiota et al., 2013). The high values indicate an increase in blood flow from the central nucleus to the animal surface, and consequently an increase in heat flow rate, which results in an increased ST (Souza et al., 2007).

Bovines and other ruminants are homeothermic animals, tending to maintain a constant body temperature through the heat flow determined by processes that depend on temperature and relative air humidity. When these animals are kept in high-temperature environments, in which heat production exceeds dissipation, most sources of endogenous heat are decreased (mainly feed intake), while body temperature, respiratory rate, sweating rate, and heartbeats increase. This happens due to the involvement of physical, biochemical, and physiological processes that to try to neutralize the negative effects of heat stress and maintain thermal equilibrium. When changes in these parameters occur, give indications of the animal's attempt to minimize the thermal imbalance (Pinheiro et al., 2015).

Souza et al. (2007) analyzed the physiological parameters and heat tolerance index in Sindhi cattle and observed higher averages of surface temperatures in the afternoon when compared to that observed in the morning during dry and rainy seasons. This shows that under a severe stress, an increase in blood flow occurs from the central nucleus to the animal surface and hence a high heat flow rate, resulting in high surface temperatures.

The creatinine concentration is within the range of 1.0 to $2.0 \mathrm{mg} / \mathrm{dL}$ estimated for cattle (Ferreira et al., 2009). High sodium concentrations in the blood can trigger hypertension and consequently affect the functioning of the kidneys. However, serum creatinine level is used to assess the glomerular filtration rate because when the levels are high, it means that the kidneys are not working properly (İssi, Gül \& Başbuğ, 2016). This fact did not occur in our study, indicating that, although the animals have consumed water with a high STD level, the functioning of the kidneys was not impaired.

The results found for serum sodium levels are within the reference values of 130 to $145 \mathrm{mmol} / \mathrm{L}$ for cattle (Ferreira et al., 2009). As sodium intake increases, its output is slightly delayed in relation to its intake and this delay results in a small increase in the cumulative sodium balance, which causes a slight increase in the volume of the extracellular fluid (Guyton \& Hall, 2002).

Potassium concentration is within the reference standards of 3.5 to $5 \mathrm{mmol} / \mathrm{L}$ for cattle (Ferreira et al., 2009). Possibly these values did not differ because of the ability of the kidneys in balancing this ion. Potassium balance involves a change in its excretion. When there is a high intake of this ion, secretion exceeds reabsorption and its excess is excreted through the urine in order to maintain its equilibrium in the extracellular fluid (Zacchia, Abategiovanni, Stratigis, \& Capasso, 2016).

\section{Conclusion}

Water with up to $8,326 \mathrm{mg} / \mathrm{L}$ TDS can be used in the watering of Sindhi heifers in short periods during the season of highest water shortage without affecting the ingestive behavior, physiological and serum parameters, and performance of animals.

\section{References}

Almeida, G. L. P., Pandorfi, H., Barbosa, S. B. P., Pereira, D. F., Guiselini, C., \& Almeida, G. A. P. (2013). Behavior, production and milk quality of Holstein-Gir cows under acclimatization in the corral. Revista Brasileira de Engenharia Agrícola e Ambiental, 17, 892-899. https://doi.org/10.1590/S1415-43662013000 800014

AOAC (Association of Official Analytical Chemists). (2000). Official methods of analysis (12th ed., p. 1094).

Appuhamy, J. A. D. R. N., Judy, J. V., Kebreab, E., \& Kononoff, P. J. (2016). Prediction of drinking water intake by dairy cows. Journal Dairy Science, 99, 7191-7205. https://doi.org/10.3168/jds.2016-10950

Araújo, G. G. L., Voltolini, T. V., Turco, S. H. N., \& Pereira, L. G. R. (2011). Água nos sistemas de produção de caprinos e ovinos. In T. V. Voltolini, S. A. Moraes, G. G. L. Araújo, \& R. M. Santos (Eds.), Produção de caprinos e ovinos no Semiárido (pp. 69-93). Petrolina: Embrapa Semiárido. 
Araújo, G. G. L., Voltolini, T. V., Chizzotti, M. L., Turco, S. H. N., \& Carvalho, F. F. R. (2010). Water and small ruminant production. Revista Brasileira de Zootecnia, 39, 326-336. https://doi.org/10.1590/S151635982010001300036

Beyene, T. (2016). Veterinary drug residues in feed-animal products: Its risk factors and potential effects on public health. Journal of Veterinary Science \& Technology, 7, 1-7.

Buffington, D. E., Collazo-Arocho, A., Canton, G. H., Pitt, D., Thatcher, W. W., \& Collier, R. J. (1981). Black globe-humidity index (BGHI) as comfort equation for dairy cows. Transactions of the ASAE, 1, 711-713. https://doi.org/10.13031/2013.34325

Bürger, P. J., Pereira, J. C., Queiroz, A. C., Coelho da Silva, J. F., Valadares Filho, S. C., Cecon, P. R., \& Casali, A. D. P. (2000). Ingestive behavior in Holstein calves fed diets with different concentrate levels. Revista Brasileira de Zootecnia, 29, 236-242. https://doi.org/10.1590/S1516-35982000000100031

Chacur, M. G. M., Bastos, G. P., Vivian, D. S., Silva, L., Chiari, L. N. F., Araujo, J. S.,... Gabriel Filho, L. R. A. (2016). Use of infrared thermography to evaluate the influence of the climatic factors in the reproduction and lactation of dairy cattle. Acta Scientiae Veterinariae, 44, 1-10.

Church, D. C. (1993). The Ruminant Animal: Digestive physiology and nutrition (3rd ed., p. 640). Zaragoza: Acribia.

Cirilo, J. A. (2008). Public water resources policy for the semi-arid region Estudos Avançados, 22, 61-82. https://doi.org/10.1590/S0103-40142008000200005

Correia, B. R., Oliveira, R. L., Jaeger, S. M. P. L., Bagaldo, A. R., Carvalho, G. G. P., Oliveira, G. J. C., ... Oliveira, P. A. (2012). Ingestive behavior and physiological parameters of steers fed with biodiesel cakes. Archivos de Zootecnia, 61, 79-89. https://doi.org/10.4321/S0004-05922012000100009

Das, R., Sailo, L., Verma, N., Pranay Bharti, P., Saikia, J., Imtiwati, I., \& Kumar, R. (2016). Impact of heat stress on health and performance of dairy animals: A review. Veterinary World, 9, 260-268. https://doi.org/10.14202/vetworld.2016.260-268

Dash, S., Chakravarty, A. K., Singh, A., Upadhyay, A., Singh, M., \& Yousuf, S. (2016). Effect of heat stress on reproductive performances of dairy cattle and buffaloes: A review. Veterinary World, 9, 235-244. https://doi.org/10.14202/vetworld.2016.235-244

EMBRAPA (Brazilian Agricultural Research Corporation). (2014). Weather data. Retrieved from http://www.cpatsa.embrapa.br:8080/servicos/dadosmet/ceb-dia.html

Ferreira, F., Campos, W. E., Carvalho, A. U., Pires, M. F. A., Martinez, M. L., Silva, M. V. G. B., ... Silva, P. F. (2009). Clinical, hematological, biochemical, and hormonal parameters of cattle submitted to heat stress. Arquivo Brasileiro de Medicina Veterinária e Zootecnia, 61, 769-776. https://doi.org/10.1590/S010209352009000400002

Furtado, D. A., Peixoto, A. P., Regis, J. E. F., Nascimento, J. W. B., Araújo, T. G. P., \& Lisboa, A. C. C. (2012). Thermoregulation and performance of Sind and Guzera young bulls in 'Agreste' region of Paraiba state. Revista Brasileira de Engenharia Agricola e Ambiental, 16, 1022-1028. https://doi.org/10.1590/S141543662012000900014

Geron, L. J. V., Aguiar, S. C., Garcia, J., Zeoula, L. M., Coelho, K. S. M., Santos, I. S., ... Diniz, L. C. (2018). Distiller's dried grain with solubles (Zea mays L.) in the diet of sheep reared in the tropical region of Brazil: Ingestive behavior and physiological parameters. Semina: Ciências Agrárias, 39, 1267-1280. https://doi.org/10.5433/1679-0359.2018v39n3p1267

Guyton, A., \& Hall, J. E. (2011). Tratado de fisiologia médica (12th ed., p. 1014). Rio de Janeiro: Elsevier.

Hall, M. B. (2000). Calculation of non-structural carbohydrate content of feeds that contain non-protein nitrogen (Bulletin 339, p. A-25). Gainesville: University of Florida.

İssi, M., Gül, Y., \& Başbuğ, O. (2016). Evaluation of renal and hepatic functions in cattle with subclinical and clinical ketosis. Turkish Journal of Veterinary and Animal Sciences, 40, 47-52. https://doi.org/10.3906/ vet-1505-16

Johansson, K. (2008). Salt to ruminants and horses (p. 34). Department of Animal Nutrition and Management, Swedish University of Agricultural Sciences, Uppsala. 
Johnson, T. R., \& Combs, D. K. (1991). Effects of prepartum diet, inert rumen bulk, and dietary polythylene glicol on dry matter intake of lactating dairy cows. Journal Dairy Science, 74, 933-944. https://doi.org/ 10.3168/jds.S0022-0302(91)78243-X

Licitra, G., Hernandez, T. M., \& Van Soest, P. J. (1996). Standardization of procedures for nitrogen fracionation of ruminant feed. Animal Feed Science and Technology, 57, 347-358. https://oi.org/10.1016/ 0377-8401(95)00837-3

Marwick, G. (2007). Water requirements for sheep and cattle. Profitable and sustainable primary industry (3rd ed., p. 5). Australian: Agriculture NSW.

Mertens, D. R. (2002). Gravimetric determination of amylase-treated neutral detergent fiber in feeds with refluxing in beaker or crucibles: Collaborative study. Journal of AOAC International, 85, 1217-1240.

Nascimento, G. V., Cardoso, E. A., Batista, N. B., Souza B.B., Cambuí, G.B. (2013). Productive indicators physiological and behavioral cows milk. Agropecuária Científica no Semiárido, 9, 28-36.

NRC (National Research Council). (1996). Nutrients requeriments of beef cattle (7th ed.). National Academy Press, Washington, D.C.

NRC (National Research Council). (2001). Nutrients requeriments of dairy cattle (6th ed.). National Academy Press, Washington, D.C.

NRC (National Research Council). (2007). Nutrient requirements of small ruminants: Sheep, goats, cervids, and new world camelids (8th ed.). National Academy Press, Washington, DC.

Oliveira, K. M., Castro, G. H. F., Herculano, B. N., Mourthé, M. H. F., Santos, R. A., \& Pires, A. V. (2016). Ingestive behavior of dairy catle fed crambe bran. Arquivo Brasileiro de Medicina Veterinária e Zootecnia, 68, 439-447. https://doi.org/10.1590/1678-4162-7995

Oliveira, P. T. L., Turco, S. H. N., Araújo, G. G. L., Voltolini, T. V., Menezes, D. R., \& Silva, T. G. F. (2012). Ingestive behavior and physiological parameters of Sindhi cattle fed increasing levels of saltbush hay Revista Brasileira de Ciências Agrárias, 7, 180-188. https://doi.org/10.5039/agraria.v7ila914

Pahl, C., Hartung, E., Mahlkow-Nerge, K., \& Haeussermann, A. (2015). Feeding characteristics and rumination time of dairy cows around estrus. Journal of Dairy Science, 98, 148-154. https://doi.org/10.3168/ jds.2014-8025

Paiva, G. N., Araújo, G. G. L., Henriques, L. T., Medeiros, A. N., Beltrão Filho, E. M., Costa, R. G., ... Freire, R. M. B. (2017). Water with different salinity levels for lactating goats. Semina: Ciências Agrárias, 38, 2065-2074. https://doi.org/10.5433/1679-0359.2017v38n4p2065

Pazdiora, R. D., Brondani, I. L., Silveira, M. F., Arboitte, M. Z., Cattelam, J., \& Paula, P. C. (2011). Effects of supply frequency of roughage and concentrate on ingestive behavior of feedlot cows and heifers Revista Brasileira de Zootecnia, 40, 2244-2251. https://doi.org/10.1590/S1516-35982011001000026

Plumb, S. C. (1927). Water consumption by sheep. Journal of Animal Science, 1, 109-112.

Pinheiro A. C. P., Saraiva, E. P., Saraiva, C. A. S., Fonseca, V. F. C., Almeida, M. E. V., Santos, S. G. G. C., ... Rodrigues Neto, P. J. (2015). Anatomical and physiological characteristics of dairy cattle to adapt to the tropical environment. Agropecuária Técnica, 36, 280-293.

Pinto, A. P., Marques, J. A., Abrahão, J. J. S., Nascimento, W. G., Costa, M. A. T., \& Lugão, S. M. B. (2010). Comportamento e eficiência ingestiva de tourinhos mestiços confinados com três dietas diferentes. Archivos de Zootecnia, 59, 427-434. https://doi.org/10.4321/S0004-05922010000300010

Potter, B. J., Walker, D. J., \& Forrest, W. W. (1972). Changes in intraruminal function of sheep when drinking saline water. British Journal of Nutrition, 27, 75-83. https://doi.org/10.1079/BJN19720071

Rakova, N., Kitada, K., Lerchl, K., Dahlmann, A., Birukov, A., Daub, S., ... Titze, J. (2017). Increased salt consumption induces body water conservation and decreases fluid intake. The Journal of Clinical Investigation, 127, 1932-1943. https://doi.org/10.1172/JCI88530

Randhawa, S. S., Chhabra, S., Randhawa, C. S., Zahid, U., \& Dhaliwa, P. S. (2014). A note on treatment of hyperthermia in crossbred cattle. Asian Pacific Journal of Tropical Biomedicine, 4, 272-274. https://doi.org/ 10.12980/APJTB.4.2014C179 
Rejeb, M., Sadraoui, R., Najar, T., \& M'rad, M. B. (2016). A complex interrelationship between rectal temperature and dairy cows' performance under heat stress conditions. Open Journal of Animal Sciences, 6 , 24-30. https://doi.org/10.4236/ojas.2016.61004

Santos, N. M. S. S., Queiroz, M. A. A., Araújo, G. G. L., Costa, S. A. P., Albuquerque, I. R. R., Moura, J. H. A., ... Manera, D. B. (2014). Salinity in the drinking water of sheep and use of their manure for cultivation of maize seedlings. Ciência Rural, 44, 531-537. https://doi.org/10.1590/S0103-84782014000300023

SAS. (2009). SAS user's guide (Version 9.2). Cary: SAS Institute.

Schlink, A. C., Nguyen, M. L., \& Viljoen, G. J. (2010). Water requirements for livestock production: A global perspective. Revue Scientifique et Technique, 29, 603-19. https://doi.org/10.20506/rst.29.3.1999

Schütz, K. E., Lee, C., \& DeVries, T. J. (2018). 5-Cattle priorities: Feed and water selection, ability to move freely and to access pasture. Advances in Cattle Welfare, 1, 93-122. https://doi.org/10.1016/B978-0-08100938-3.00005-X

Segabinazzi, L. R., Menezes, L. F. G., Silva, C. E. K., Martinello, C., Boito, B., \& Molinete, M. L. (2014). Diurnal ingestive behavior of Holstein calves reared in different systems: Feedlot or pasture. Acta Scientiarum. Animal Sciences, 36, 225-231. https://doi.org/10.4025/actascianimsci.v36i2.22653

Shiota, A. M., Santos, S. F., Nascimento, M. R. B. M, Moura, A. R. F., Oliveira, M. V., \& Ferreira, I. C. (2013). Physiological parameters, hair coat characteristics and thermal gradients in Nellore heifers in summer and winter in tropical environment. Bioscience Journal, 29, 1687-1695.

Silva, W. R., Silva, M. R., \& Pires, T. B. (2014). O uso sustentável e a qualidade da água na produção animal. Nutritime Revista Eletrônica, 11, 3617-3636.

Silva, D. J. S., \& Queiroz, A. C. (2002). Analise de alimentos: métodos químicos e biológicos (3rd ed., p. 235). Viçosa: UFV.

Sniffen, C. J., O’Connor, J. D., Van Soest, P. J., Fox, D. G., \& Russell, J. B. (1992). A net carbohydrate and protein system for evaluating cattle diets: II. Carbohydrate and protein availability. Journal Animal Science, 70, 3562-3577. https://doi.org/10.2527/1992.70113562x

Souza, B. B., Silva, R. M. N., Marinho, M. L., Silva, G. A., Silva, E. M. N, \& Souza, A. P. (2007). Physiological parameters and heat tolerance index of Sindi breed bovine in the semi-arid of Paraiba. Ciência $e$ Agrotecnologia, 31, 883-888. https://doi.org/10.1590/S1413-70542007000300040

Udmale, P., Ichikawa, Y., Manandhar, S., Ishidaira, H., \& Kiem, A. S. (2014). Farmers' perception of drought impacts, local adaptation and administrative mitigation measures in Maharashtra State, India. International Journal of Disaster Risk Reduction, 10, 250-269. https://doi.org/10.1016/j.ijdrr.2014.09.011

Valente-Campos, S., Nascimento, E. S., \& Umbuzeiro, G. A. (2014). Water quality criteria for livestock watering: A comparison among different regulations. Acta Scientiarum. Animal Sciences, 36, 01-10. https://doi.org/10.4025/actascianimsci.v36i1.21853

Van Soest, P. J., Robertson, J. B., \& Lewis, B. A. (1991). Symposium: Carbohydrate metodology, metabolism, and nutritional implications in dairy cattle. Journal Dairy Science, 74, 3583-3597. https://doi.org/10.3168/ jds.S0022-0302(91)78551-2

Valtorta, S. E., Gallardo, M. R., Gregoret, R. F., Conti, G. A., Gandolfo, J. A., \& Leva, P. E. (2005). Efecto de la salinidad sobre el consumo de água de vacas lecheras em lactancia durante períodos cálidos. Paper presented at the $28^{\circ}$ Congresso Argentino de Producción Animal, Bahía Blanca-Argentina. Retrieved from http://www.produccion-animal.com.ar/agua_bebida/19-Efecto_salinidad_sobre_consumo.pdf

Zacchia, M., Abategiovanni, M. L, Stratigis, S., \& Capasso, G. (2016). Potassium: From Physiology to Clinical Implications. Kidney Diseases (Basel), 2, 72-79. https://doi.org/10.1159/000446268

\section{Copyrights}

Copyright for this article is retained by the author(s), with first publication rights granted to the journal.

This is an open-access article distributed under the terms and conditions of the Creative Commons Attribution license (http://creativecommons.org/licenses/by/4.0/). 